\section{Dermatologists wearing white coats on practice websites: current trends.}

\author{
Ryan G. Gamble, ${ }^{1}$ Ashley A. Hay, ${ }^{2}$ \\ Jeffrey H. Dunn, ${ }^{1}$ \\ Robert P. Dellavalle $e^{1,3,4}$ \\ 1 Department of Dermatology, University \\ of Colorado Denver, Aurora, CO; \\ 2Loma Linda University School of \\ Medicine, Loma Linda, CA; \\ ${ }^{3}$ Department of Epidemiology, Colorado \\ School of Public Health, University of \\ Colorado Denver, Aurora, CO; \\ ${ }^{4}$ Department of Dermatology, Denver \\ Veterans Administration Hospital, \\ Denver, CO, USA
}

\section{Abstract}

Physicians wearing white coats are perceived as having more authority, being more friendly and being more attractive than those not wearing white coats, and patients report that they prefer their dermatologist to wear a white coat. The aim of the study was to determine the prevalence of dermatologists wearing white coats on practice websites. We searched Google for dermatology practice websites in six states representing distinct geographic regions in the United States. The first one hundred search results were evaluated, and photographs of dermatologists on these websites were examined for the presence or absence of white coats. Most (77\%) of dermatologists did not wear white coats. The highest prevalence was in the eastern states of Massachusetts and South Carolina, with 29\% and $39 \%$, respectively. Colorado had the lowest rate at $13 \%$. Rates were essentially equal when segmented by gender. Although patients report that they prefer their dermatologist to wear a white coat, dermatologists often do not wear a white coat on their practice websites.

\section{Introduction}

To wear or not to wear - that is the white coat question. Today fewer physicians wear them while more non-physician health care professionals do. Several studies over the past 20 years have addressed patient preferences on the matter. A review of the literature, including two dermatology studies, indicates that patients prefer their physicians to wear white coats, not only for identification purposes but to build trust and confidence. ${ }^{1-7}$ This preference holds stable whether studies have addressed general practitioners, ${ }^{1-4}$ specialists, ${ }^{5}$ or dermatologists specifically. ${ }^{6,7}$ A study in which subjects were shown digital photographs of doctors with or without white coats found that subjects perceived the doctors wearing white coats to have greater authority, to be more friendly and to be more attractive. ${ }^{8}$ No study has assessed the prevalence of dermatologists wearing white coats on their websites. Given that patient preferences are well known and that websites are a major marketing and communication tool, we conducted an observational study to evaluate the prevalence of dermatologists in white coats on websites.

\section{Materials and Methods}

To estimate national trends, we evaluated six states from varying regions: northwest (Oregon), southwest (Arizona), west (Colorado), midwest (Indiana), northeast (Massachusetts), and southeast (South Carolina). State populations ranged from 3.86.6 million. $^{9}$

One author (AH) used Google to search the terms Arizona dermatology, Colorado dermatology, Indiana dermatology, Massachusetts dermatology, Oregon dermatology, and South Carolina dermatology. During October 18-24, 2010 she evaluated the first 100 websites for each search term, assessing for relevancy, redundancy, and English language use. She evaluated both photos and videos of dermatologists. If multiple photos or videos of a dermatologist existed on the site, she only recorded one image per dermatologist with the profile image taking priority. She recorded the total number of dermatologists, their gender, and whether they were photographed with or without white coats.

\section{Results}

Table 1 summarizes the prevalence of dermatologists wearing white coats in each state. Overall, $23 \%$ of dermatologists wore white coats, while $77 \%$ did not. Massachusetts and South Carolina had the highest white coat prevalence rate at $29 \%$ and $39 \%$, respectively. Colorado had the lowest rate at $13 \%$, one third of South Carolina's rate. Rates were essentially equal overall and when considering gender. There was moderate variation by gender between various states: Arizona and Colorado had a higher prevalence of women wearing white coats, while the other four states had a higher prevalence of white coat-wearing men.
Correspondence: Robert P. Dellavalle, Dermatology Service, Department of Veteran Affairs Medical Center, 1055 Clermont Street, Box 165, Denver, C0 80220, USA.

Tel. +1.303 .399 .8020 , ext. 2475 - Fax. +1.303 .393 .4686 . E-mail: robert.dellavalle@ucdenver.edu

Key words: white coat, dermatologist, websites, online.

Contributions: RPD, RGG, AAH, study concept and design; AAH, RGG, data acquisition, analysis and interpretation of data; AAH, RGG manuscript drafting; JHD, RPD, RGG, AAH, manuscript critical revision; RPD administrative, technical and material support, study supervision.

Conflict of interest: the authors report no conflicts of interest.

Received for publication: 3 June 2011. Accepted for publication: 5 June 2011.

This work is licensed under a Creative Commons Attribution NonCommercial 3.0 License (CC BYNC 3.0).

(C) Copyright R.G. Gamble et al., 2011

Licensee PAGEPress, Italy

Dermatology Reports 2011; 3:e6

doi:10.4081/dr.2011.e6

\section{Discussion}

The results indicate that, on their websites at least, dermatologists are largely not wearing white coats. Prevalence rates vary by state, but in all six states the majority of dermatologists did not wear white coats. The east coast is customarily known for being more traditional, which may account for its relatively high white coat prevalence rate.

Physicians report various reasons for not wanting to wear white coats - infection risk, discomfort, and interfering with the patientphysician relationship. ${ }^{1}$ However, a recent study found no statistically significant difference between bacterial or methicillin-resistant Staphylococcus aureus contamination of physician's white coats versus newly laundered physician attire after an eight hour work day. ${ }^{1}$ The study also found no difference in bacterial contamination at the wrists of doctors wearing white coats versus newly laundered attire, suggesting that white coats may pose no greater risk of infection than newly laundered clothing. Further, infection risk and comfort are not significant concerns when posing for a photo for one's website. A recent study on dermatology patients indicates that most patients prefer their dermatologist to wear a white coat ${ }^{2}$ while a study involving digital images of doctors with and without white coats patients perceive doctors to have more authority, be 
Table 1 . White coat prevalence by state. ${ }^{a}$

\begin{tabular}{lccccccc} 
& Arizona & Colorado & Indiana & Massachusetts & Oregon & $\begin{array}{c}\text { South } \\
\text { Carolina }\end{array}$ & Total \\
$\begin{array}{l}\text { Total: } \\
\text { white } \\
\text { coats }\end{array}$ & $17 \%(13)$ & $13 \%(12)$ & $20 \%(11)$ & $29 \%(38)$ & $20 \%(12)$ & $39 \%(23)$ & $23 \%(109)$ \\
$\begin{array}{l}\text { Total: } \\
\text { no } \\
\text { white } \\
\text { coats }\end{array}$ & $3 \%(64)$ & $87 \%(82)$ & $80 \%(43)$ & $71 \%(91)$ & $80 \%(48)$ & $61 \%(36)$ & $77 \%(364)$ \\
$\begin{array}{l}\text { Men: } \\
\text { white }\end{array}$ & $11 \%(5)$ & $8 \%(4)$ & $23 \%(8)$ & $33 \%(21)$ & $21 \%(7)$ & $43 \%(16)$ & $23 \%(61)$ \\
$\begin{array}{l}\text { coats } \\
\text { Men: } \\
\text { no } \\
\text { white } \\
\text { coats }\end{array}$ & $89 \%(41)$ & $92 \%(47)$ & $77 \%(27)$ & $67 \%(42)$ & $79 \%(26)$ & $57 \%(21)$ & $77 \%(204)$ \\
$\begin{array}{l}\text { Women: } \\
\text { white } \\
\text { coats }\end{array}$ & $26 \%(8)$ & $19 \%(8)$ & $16 \%(3)$ & $26 \%(17)$ & $19 \%(5)$ & $32 \%(7)$ & $23 \%(48)$ \\
$\begin{array}{l}\text { Women: } \\
\text { no } \\
\text { white } \\
\text { coats }\end{array}$ & $74 \%(23)$ & $81 \%(35)$ & $84 \%(16)$ & $74 \%(49)$ & $81 \%(22)$ & $68 \%(15)$ & $77 \%(160)$ \\
\hline
\end{tabular}

aData expressed as percent (number).

more friendly and be more attractive when they are wearing a white coat. ${ }^{8}$ While white coats can provoke anxiety in some, such as in reported white coat hypertension, they may also have a positive placebo effect in others. ${ }^{10}$ Since many non-physician healthcare professionals also wear white coats, white coats may not be as helpful to patients for identification of the physician as they once were. This is not a reason to forgo a white coat. Rather, identification badges clearly marked as doctor or physician may help to alleviate confusion for patients. ${ }^{1}$ Our findings are limited by having only examined images on websites in six states. However, we chose states in distinct geographic areas of the country in an effort to measure a representative sample of the entire United States. It is also possible that photographs on websites do not accurately reflect dermatologist attire in the office. Photographs on websites are nonetheless important. As most dermatologists' websites are designed primarily to market their practice, it would follow that they should accommodate patient preferences. While recruiting new patients through the Internet currently may not be paramount, using practice websites as advertising tools is likely to become more important as younger patients turn to the web to find medical information and recommendations for health care providers. ${ }^{12}$ Thus, as dermatologists develop and update their websites, we suggest donning a white coat to visually brand medical professionalism.

\section{Conclusion}

In our study sample, most (77\%) dermatologists did not wear white coats on their practice website. Our results were approximately equal among men and women, but East coast states had the highest rates of white coat-wearing physicians (29\% in Massachusetts and 39\% in South Carolina), whereas Colorado had the lowest rate (13\%). Since patients report they prefer their dermatologist wear a white coat, and practice websites may be patients' first introduction to their dermatologists, dermatologists should consider presenting themselves wearing white coats online.

\section{References}

1. Douse J, Derrett-Smith E, Dheda K, Dilworth JP. Should doctors wear white coats? Postgrad Med J 2004;80:284-6.

2. Tiwari A, Abeysinghe N, Hall A, et al. Should doctors wear white coats? The patient's perspective. J Eval Clin Pract 2000;7:343-5.

3. Rehman SU, Nietert PJ, Cope DW, Kilpatrick A. What to wear today? Effect of doctor's attire on the trust and confidence of patients. Am J Med 2005;118:1279-86.

4. Gooden BR, Smith MJ, Tattersall SJ, Stockler MR. Hospitalised patients' views on doctors and white coats. Med J Aust 2001;175:219-22.

5. Cha A, Hecht BR, Nelson K, Hopkins MP. Resident physician attire: does it make a difference to our patients? Am J Obstet Gynecol 2004;190:1484-8.

6. Kanzler MH, Gorsulowsky DC. Patients' attitudes regarding physical characteristics of medical care providers in dermatologic practices. Arch Dermatol 2002;138: 463-6.

7. Thomas MW, Burkhart CN, LugoSomolinos A, Morrell DS. Patients' perceptions of physician attire in dermatology clinics. Arch Dermatol 2011;147:505-6.

8. Brase GL, Richmond J. The white-coat effect: physician attire and perceived authority, friendliness, and attractiveness. J Applied Soc Psychol. 2004;34:2469-81.

9. U.S. Census Bureau. Available from: http://quickfacts.census.gov/qfd/states.

10. Ellis CN. Practice Gaps--Patient Preference vs Personal Preference, and What Should I Wear Today? Arch Dermatol 2011;147:506-7.

11. Burden M, Cervantes L, Weed D, et al. Newly cleaned physician uniforms and infrequently washed white coats have similar rates of bacterial contamination after an 8-hour workday: A randomized controlled trial. J Hosp Med 2011;6:109-14.

12. Schuh C. Medical pioneers in cyberspace: German practice owners advertising on the WWW. J Med Internet Res 1999;1:E2. 